\begin{tabular}{|l|l|l|}
\hline \multicolumn{2}{|c|}{ PublisherInfo } \\
\hline \hline PublisherName & $:$ & BioMed Central \\
\hline \hline PublisherLocation & $:$ & London \\
\hline \hline PublisherImprintName & $:$ & BioMed Central \\
\hline \hline
\end{tabular}

\title{
Tight glucose control in the critically ill improves survival
}

\begin{tabular}{|c|c|c|}
\hline \multicolumn{3}{|c|}{ ArticleInfo } \\
\hline ArticleID & : & 4321 \\
\hline ArticleDOI & : & $10.1186 /$ ccf-2001-73700 \\
\hline ArticleCitationID & : & 73700 \\
\hline ArticleSequenceNumber & : & 32 \\
\hline ArticleCategory & : & Paper Report \\
\hline ArticleFirstPage & : & 1 \\
\hline ArticleLastPage & : & 4 \\
\hline ArticleHistory & : & $\begin{array}{ll}\text { RegistrationDate } & : 2001-12-6 \\
\text { Received } & : 2001-11-21 \\
\text { OnlineDate } & : 2001-12-6\end{array}$ \\
\hline ArticleCopyright & : & Biomed Central Ltd2001 \\
\hline ArticleGrants & ( & \\
\hline ArticleContext & : & 1305455 \\
\hline
\end{tabular}


Aff1 Mayo Clinic, Rochester, MN, USA

\section{Keywords}

Hyperglycemia, multiple organ failure

\section{Context}

Stress induced hyperglycemia is common in critically ill patients and may be associated with an increased rate of infectious complications (see Additional information [1]). Harmful effects of growth hormone therapy (see Additional information [2]) and parenteral nutrition (see Additional information [3]) may be related, at least in part, to the prevalence of hyperglycemia in critically ill patients. Intensive glucose management has been shown to improve survival in patients with diabetes mellitus and acute myocardial infarction (see Additional information [4]). This controlled trial investigates glucose management in nondiabetic surgical and critically ill patients.

\section{Significant findings}

In total, 1548 patients were enrolled. There were no significant differences between the intensivetherapy group and control group at randomization.

Following intervention the mean morning glucose levels were $103 \mathrm{mg} / \mathrm{dl}$ in the intensive-therapy group versus $153 \mathrm{mg} / \mathrm{dl}$ in the control group. Crude hospital mortality was $7.2 \%$ in the intensive-therapy group and $10.9 \%$ in the control group $(P=0.01)$. The benefit was even more significant in the subgroup of patients receiving intensive care for $>5$ days (mortality rate $16.8 \%$ versus $26.3 \%$ ). The mortality benefit was associated with a $46 \%$ decrease in bloodstream infections.

\section{Comments}

Although nonblinded and restricted to patients undergoing cardiac surgery this study will, in all likelihood, have a great impact on the management of critically ill patients. For diabetic patients with acute myocardial infarction and for patients with or without diabetes mellitus recovering from cardiac 
surgery, data appear strong. There is no reason to believe this would not be applicable to critically ill patients in general.

\section{Methods}

Patients receiving mechanical ventilation in a cardiac surgery intensive care unit were randomized to conventional (insulin drip only if blood glucose level above $200 \mathrm{mg} / \mathrm{dl}$ ) and strict glucose control (insulin drip to maintain normal blood glucose level [80-110 mg/dl]).

\section{Additional information}

1. McCowen KC, Malhotra A, Bistrian BR: Stress-induced hyperglycemia.

Crit Care Clin 2001, 17:107-124.

2. Takala J, Ruokonen E, Webster NR, Nielsen MS, Zandstra DF, Vundelinckx G, Hinds CJ: Increased mortality associated with growth hormone treatment in critically ill adults. $N$ Engl J Med 1999, 341:785-792.

3. Heyland DK, MacDonald S, Keefe L, Drover JW: Total parenteral nutrition in the critically ill patient: a meta-analysis. JAMA 1998, 280:2013-2019.

4. Malmberg K, Norhammar A, Wedel H, Ryden L: Glycometabolic state at admission: important risk marker of mortality in conventionally treated patients with diabetes mellitus and acute myocardial infarction: long-term results from the Diabetes and Insulin-Glucose Infusion in Acute Myocardial Infarction (DIGAMI) study. Circulation 1999, 99:2626-2632.

There is an editorial in the same issue:

Evans TW: Hemodynamic and metabolic therapy in critically ill patients. $N$ Engl J Med 2001, 345:1417-1418. 


\section{References}

1. Van den Berghe G, Wouters P, Weekers F, Verwaest C, Bruyninckx F, Schetz M, Vlasselaers D, Ferdinande P, Lauwers P, Bouillon R: Intensive insulin therapy in critically ill patients. New Engl J Med. 2001, 345: 1359-1367. 